\title{
Media Control On Corruption In Local Goverment ; Create Clean And Justice Government In South Sulawesi Province (Analysis of the Role of the Media in the Era of Regional Autonomy)
}

\author{
Hafied Cangara \\ Department of Communication Studies, \\ Faculty of Social and Political Sciences, \\ Hasanuddin University, Indonesia. \\ Subhan Amir \\ Department of Communication Studies, \\ Faculty of Social and Political Sciences, \\ Hasanuddin University, Indonesia. \\ Nosakros Arya \\ Department of Communication Studies, \\ Faculty of Social and Political Sciences, \\ Hasanuddin University, Indonesia.
}

\begin{abstract}
This study aims to determine the role of community newspaper in carrying out its oversight function of corruption in South Sulawesi province, Indonesia. The type of research used is the content analysis and in-depth interviews with several key informants, including the mayor, the attorney general, the police, non-governmental organizations, and newspaper publishers. The unit of analysis is four local newspapers namely Pare Pos, Palopo Pos, Radar Bone and Radar Selatan. These four newspapers were published outside the provincial capital of South Sulawesi, Makassar. Data analysis used the Single Factor Analysis of variance (ANOVA) or one-factor ANOVA (One Way ANOVA) test. The findings of the study show that: (1) the media has a role in carrying out its oversight function of corruption in government institutions in South Sulawesi, although this is not solely because of the media, but also the regulation and supervision carried out by the government through the bureaucratic path, (2) The portion of community newspaper coverage of corruption is quite large compared to other themes. However, judging from the tone of the news in general, it is still nuanced with information, and there has not been much investigated reporting. (3) Judging from the frequency of the coverage of these four newspapers, the Palopo Pos Daily and Radar Bone Daily showed a trend in reporting corruption issues, while the Pare Pos and Radar Selatan Daily tended to focus more on public service issues, for example waste, road, drinking water, electricity and traffic problems. However, statistical analysis showed that the difference was not significant.
\end{abstract}

Keywords: Community media, local government, , corruption, clean governance, regional autonomy

\section{PRELIMINARY}

The adoption of Indonesia Law No. 32 of 2004 concerning the transfer of authority from the central government to the regions on consideration of empowering local communities. Therefore Regional Autonomy is a political offer that wants changes and development of a faster society towards self-determination and sharing of power for government. Regional 
autonomy is expected to be able to balance power between the central government and regional governments, and create political interaction to encourage people to apply democratic principles in the state through empowering political institutions and good governance reforms. The practice of expanding districts and cities in Indonesia over the past 15 years is expected to accelerate regional development by managing the potential of natural resources and human resources to be able to finance their regions. With such expectations, the local government is given the opportunity to create and innovate more.

Regional autonomy with regional expansion should be based on objective reasons, namely to optimize regional potential or improve government management in totality. Therefore. In the future, there is a need for regulations that emphasize the meaning of autonomy, rights and obligations of autonomous regions, basic criteria as a prerequisite for regions that want expansion. It can be said that since the regional autonomy law was implemented, not a few political officials (governors, mayors, leaders and members of parliament) and bureaucratic officials in various regions in Indonesia were involved in corruption cases. Whether he is still a suspect, defendant or convicted is often used as a news item for journalists. These people abuse their authority and accept bribes in amounts ranging from hundreds of millions to billions of rupiah. It is indeed quite sad to see these community leaders being led into prison by the Indonesian Corruption Eradication Commission.

The corruption cases involving many political officials, assessed by The Habibie Center researcher Andrinof A. Chaniago are due to the large political costs that must be incurred by politicians in regional and parliamentary elections and the increasing role of legislative and executive powers in the regions as little king in his area of authority. Chaniago further stated that the phenomenon of corruption in the era of regional autonomy shows that there is a lack of clarity in the accountability of regional heads to local communities, as well as the form of responsibility of regional heads to the public is unclear. Here the public never knows how the bureaucracy performs in the area.

The Republic of Indonesia's Ministry of Home Affairs noted that 309 regional heads had been caught in corruption cases since the direct regional elections in 2005. The magnitude of the danger of corruption on the mental attitude of government officials in Indonesia and the continuity of national development, the press in this case the journalists have a control function on the running of the government and also to service to the public (Law Number 40 of 1999).

The Indonesian press has the role of conducting supervision, criticism, correction and suggestions on matters relating to the public interest and fighting for justice and truth. However, sometimes the media are not professional enough to carry out their control functions, especially in this reform era, the media can play a greater role considering the principle of transparency is a necessity in creating good and clean governance, and the public's right to public opinion and the right to obtain information.

\section{Formulation of the problem}

Based on what has been described above, the formulation of the research problem can be arranged as follows: (1) Does the press get closer to the target object of the news, then the community media can carry out its oversight function on acts of corruption that occur in South Sulawesi? How big is the portion of coverage about corruption committed by community media in uncovering corrupt cases ?, and (3) Is there a difference between the coverage of community media in carrying out its control function on matters relating to abuse of authority (corruption) in South Sulawesi? 


\section{Research purposes}

This study aims to find out: (1) The role of community media published in South Sulawesi in carrying out its oversight function of corruption in this area. (2) The amount of coverage carried out by community media in uncovering corruption cases in South Sulawesi, and (3) the differences in coverage of community media in carrying out its control function on matters relating to abuse of authority (corruption) in South Sulawesi

\section{Benefits of research}

The findings of this study are expected to be useful for: (1) the development of communication studies, (2) providing information about mapping corruption in South Sulawesi, (3) differences between community media (newspaper) in South Sulawesi in reporting corruption cases.

\section{Regional autonomy}

\section{LITERATURE REVIEW}

The definition of regional autonomy according to Mahwood is "a local government that has its own authority where its existence is separate from the authority submitted by the central government in order to allocate substantial material resources regarding different functions". There are also several notions of regional autonomy provided by some experts or experts. In the Law of the Republic of Indonesia Number 32 of 2004 concerning Regional Government, it is affirmed that Districts and Cities have the right, authority and obligation to regulate and manage their own government affairs and the interests of the local community.

\section{Implementation of Regional Autonomy}

The implementation of regional autonomy is an important focal point in order to improve people's welfare. Development of an area can be adjusted by the local government with the potential and distinctiveness of each region. This is a very good opportunity for the local government to prove its ability to exercise the authority that is the right of the region. The progress or failure of an area is largely determined by the ability and willingness of the leadership and the local community. For this reason, local governments are free to create and express themselves in order to develop their regions, of course, without violating existing legal provisions.

\section{Corruption in the Era of Regional Autonomy}

Since regional autonomy has been rolling out in 2004, corruption cases have befallen the Regents / Mayors and former Regents / Mayors, increasing every year. Data received by merdeka.com from the Corruption Eradication Commission (KPK) states that currently there are 108 Regents and Mayors and 15 Governors included in the snare, and this figure is popular in 2014 and 2019, especially ahead of Regional elections and Governors directly elected by the community .

According to Saldi Isra (2009), the proliferation of corruption in the regions can be seen through three important issues. First, consciously or not, the regional autonomy program rolled out by the government only focused on delegating authority in policy making, finance and administration from the central government to the regions, without being accompanied by the distribution of power to the public. Second, there is no state institution that is able to effectively control the deviation of authority in the region. The regional autonomy program has cut the structure of the government hierarchy, so that central government control is no longer effective in the regions because there is no direct structural relationship that forces local government compliance with the central government. Third, the regional legislature failed to carry out its function as a control institution. On the contrary there is close collusion between 
the regional government and the DPRD so that control over the implementation of regional government does not occur, while controls from civil society circles are still weak.

\section{Some Modes of Corruption \\ in the Autonomous Region}

Corruption acts can be divided into 7 categories, namely: (1) State money losses; (2) Bribery bribes; (3) embezzlement in office; (4) Extortion; (5) Cheating actions; (6) Conflict of interest in procurement; (7) Gratuities/gifts. The Habibie Center study found that there were at least 20 forms and modes of corruption, ranging from Procurement Corruption, elimination of inventory items and state assets (land), extortion of employee receipts, salary payments, promotions, pension arrangements and delaying public services. (www.tempointeraktif.com/hg).

Corruption in the regions has similar characteristics, but is concentrated in the regional head. Because of the lack of check and balance, the regional head acts like a small king. The pattern of corruption that is generally carried out is corruption of the Regional Budget or collusion with the Local Parliament (DPRD) or 'extortion' to the private sector.

The mode of corruption that occurs in many regions is as follows: Corruption of Procurement of Goods, Elimination of goods inventory and state assets (land). Extortion of employee receipts, salary payments, promotions, pension arrangements and so on, deduction of social assistance money, fictitious assistance, misappropriation of project funds, fictitious physical projects, manipulation of proceeds from receipts of taxes, levies and contributions, manipulation of physical projects, payroll or fictitious fees, manipulation of funds for physical maintenance and renovation, deduction of central government aid funds, fictitious human resource development projects, manipulation of land and building compensation, manipulation of facilities and transportation rental costs, fictitious payment of money for employees soldiers - prisoners and others, licensing extortion, extortion of population and immigration, manipulation of people's economic development projects, corruption of working time.

In connection with that, former World Bank Deputy President Jean Michel Severino said that decentralization which gave central authority to the regions (districts / cities which number 514) would be fertile ground for corruption which was difficult to monitor.

\section{Regional Autonomy and Efforts to Create Good and Clean Government}

There are three important things that must be done at the regional level in connection with good governance in the implementation of regional autonomy, First, policy transparency. This opinion arises because in the New Order era the bureaucracy's breath as a repressive tool of power was very prominent. Formulation of development and government policies that tend to be elitist, closed, and smelling nepotism. Therefore, in the era of regional autonomy, this condition is expected not to emerge again because the behavior of state administrators must prioritize the transparency of public policy. Second, community participation. Even though Law No. 22 of 1999 provides an opportunity for the DPRD to exercise control over the executive but this is felt to be insufficient because there are indications that the DPRD and the executive are "playing with the eye" in addressing strategic political policies in the region.

In order to prevent this optimal role from the community in exercising control over the implementation of government, the role of civil society and the mass media plays an important role. 


\section{RESEARCH METHODS}

This research is located in the City of Parepare and the City of Palopo within the province of South Sulawesi, Indonesia. Type of Research, which is used is Content Analysis with the aim of local print media published and circulating in the two cities and the surrounding area. According to Holsti (1969) Content analysis is a research technique for making inferences conducted objectively and systematic identification of message characteristics. While Barelson (1952) states that Content Analysis is a research technique carried out in an objective, systematic, and quantitative description of the manifest content of communication.

Types and Sources Data used are primary and secondary data. Primary data is derived from the results of newspaper coding and in-depth interviews with related sources. Secondary data is obtained from other sources that support this study. Secondary data comes from books, journals, newspapers, magazines, research reports and other significant documents for this study. Data collection techniques, namely: (1) Coding sheets using coder services to the contents of the newspapers Parepare Pos, Palopo Pos, Radar Bone, and Radar Selatan which have the theme of corruption, (2) The team also conducts in-depth interviews with relevant sources from the government, police, prosecutors, media local, and NGO parties, (3) Library Studies, and (4) Documentation.

The Analysis Unit, is news of corruption that was published in the two community media. Thus, news selection will exclude matters that are not related to the misuse of authority or violations of financial governance Standard Operational Procedure (SOP) projects or blueprints funded by State money. So this research is not only focused on the management of government, but also matters relating to the economy, social culture, politics, infrastructure that concerns the benefit of the society funded by the state or the use of authority of public officials. Analysis of the data to be used are: Frequency tables and graphs and Cross Tabulation using the Analysis of variance (ANOVA) Single Factor or one-factor ANOVA (One Way ANOVA) test.

\section{RESEARCH FINDINGS}

This research was conducted with the object of study are Pare Pos with Palopo Pos dailies. These two local newspapers are subsidiaries of Fajar daily based in Makassar.

\section{Pare Pos Daily}

Pare Pos is a daily was born as a subsidiary of Fajar and Jawa Pos. Published in the city of Parepare, the former Afdeling Ajatappareng which includes the City of Pare-pare with 4 Regencies: Sidenreng Rappang, Barru, Pinrang, and Enrekang. This newspaper was published on August 18, 2000 as a development of the Daily Fajar published in Makassar, with the aim of developing a newspaper publishing business in various regions, including Pare-pare and its surroundings.

The Pare Pos is published by PT Ajatappareng Press Intermedia with Chairman Alwi Hamu, Trustee: Syamsu Nur, President Commissioner: Andi Syafiuddin Makka with the Commissioner: Mappiare, Ibrahim Manisi, Faisal Palapa, and Nur Widyawati. Director: Harun Hamu. General Chairman: Harun Hamu, Deputy General Chief: Nur Halim, Editor in Chief: Salman Razak, Deputy Chief Editor: Fatahuddin, Editor-in-Chief: Syahrir Hakim, Editor-inChief: Khairil AR, Coverage and Online Manager: Ade Cahyadi, Editor: Ade Cahyadi, Arifuddin Beddu, Anju Mandji, Burhanuddin, Nurfadilla Wahid. Reporters: Anju Mandji, Sudarmono, Nurfadilla. Precast: Supriadi, Fajrul Islam, Joko Reski, Musyarif.

This newspaper was printed by PT Fajar Utama Intermedia in Makassar, but the circulation in Pare-pare and the surrounding area began to be published with of 500 expansions and 
distributed free of charge as a promotion. Publish with the Tagline Close to the hearts of Readers, the largest in the north of South Sulawesi. Publish daily with 12 pages, size of plano. It has a corner with the name Bici-bici mean in Bugis, a rumor from ear to ear. Contains news and advertisements, and rubrics: Public Services (Readers' Letters), Society (Community Activities), Metro Pare (Local News about Pare-pare City), Pro Rakyat (Political News), Ajatappareng Pos (news around Barru Regency, Sidenreng Rappang, Pinrang, and Enrekang), West Sulawesi (News about West Sulawesi Province), Education (Information about Education), Advertorial (Sponsor Advertising), Advertisements Rubric.

\section{Palopo Pos Daily}

The Palopo Pos Daily was published in Palopo City, South Sulawesi on March 17, 2000, is also a subsidiary of Fajar and Jawa Pos based in Makassar and Surabaya. Published by PT Palopo Press Intermedia with Chairman: Alwi Hamu, Trustee: Syamsu Nur, President Commissioner: Ir. Adil Hamu, Commissioner: Subhan Alwi Hamu, Andi Mutiara We Tenrisau, Legal Advisor: Ridwan J Silamma SH, BPP Fajar Group: Sukriansyah Latief (Chair), Suwardi Tahir (Deputy Chair), Sri Suhartini, Hendri Nasaruddin (Secretary), Mufti Hendrawan, Titik Ati (Member), Idris Hamid (Auditor). President Director: Amran Suyuti, Director: Husain Rasyid S.Pd. General Leader: Amran Suyuti, Deputy General Leader: Ikhwan Ibrahim SE, Editor in Chief/Responsible Agency: Aryanto Tanding SH, Managing Editor / Deputy Director: Idris Prasetiawan.

The Post Palopo was printed in PT FUI Palopo, with the circulation area in the former Luwu area, which included: Palopo, Makale, Masamba, Malili, Mekongga Kolaka. Post Palopo is published in plano size of 16 pages every day. Color prints and contain various kinds of news and descriptions, among others: Corner named Inspiration. Page 1 is intended for actual news around the national and regional levels. Page 1 is the Economy and Business rubric, Page 3 The Toraja and South Sulawesi Rubrics that contain news that occur around the Districts of Tana Toraja and North Toraja Regency and districts within the South Sulawesi Province. Halamana 4 is a Public Space Rubric which contains Readers' Letters and Opinions (articles). Page 5 Political Rubrics.

\section{Radar Bone Daily}

The Radar Bone Daily was first published on April 8, 2008 by PT Radar Bone, or 27 years after its parent Daily Fajar was established. This newspaper was published by PT Radar Bone with Chairman: HM Alwi Hamu, Management Advisor: H. Syamsu Nur, Chief Commissioner: Faisyal Syam, and Commissioner: Suwardi Tahir. Idris Hamid. Director Muh. Bahtiar Sairing. Ad Manager: Rosdiana Sulja. Circulation Manager: Herman Kahar. Finance and General Manager: Marizah Heriwanto. Tax Division: Wiwik Widyawati / Incasso: Muh. Yusuf (Advertisement), Hamzah latif (Circulation). Editor in Chief / Person in Charge: Muh. Bahtiar Sairing. Daily Managing / Responsible Editor: Usman Sommeng. Staff Editor: Agustapa. Askar Syam, Ardi Bin Waris, Herman. Reporter: Baharuddin, Risnawati, Adri. Photographer: Pre-printed: Muh. Risman, M. Anshar. Correspondents: Moch Sumardi (Soppeng), Lukman Sardi (Sinjai), Wahyudin (Wajo). Syamsul Bahri Arafah (South Bone and East Bone), Hendrik (West Bone).

The Radar Bone comes in 12 pages a day. The color is printed and contains a variety of news and descriptions, among others: Corner called Capila in Indonesian means chatty. Page 1 is intended for current news about the national and regional levels. Page 2 is the Economics and Business (Ecobis) rubric, Page 3 Government Political Rubric which contains legislative, executive and political party activities. Page 4 Education Rubric which contains campus activities. Page 5 Metropolis Rubric which gives news about the city of Politics, Page 6 Regional Rubric which contains news from the former District Bone area consisting of Bone, Soppeng, Wajo, and Sinjai. As a variety of space for news connections, Page 7 which contains posts / 
news connections from the previous page. Page 8 Event Rubric which contains news about crime and security by the Police. Pages 9,10 and 11 in the form of Supplement from the region under Bone District, and page 12 are the Sports rubric which contains sports news both from the national level and from the regional and local levels.

\section{Radar Selatan Daily}

The Radar Selatan Daily was first published on 7 April 2008 by PT Radar Bulukumba, or 27 years after its parent Daily Fajar was established. This newspaper was published by PT Radar Bulukumba with Chairman: HM Alwi Hamu, Advisor: H. Syamsu Nur, Chief Commissioner: Faisyal Syam, Deputy President Commissioner: Syamsul Bakir Hamid, Commissioner: Abdul Karim Alwi. Director: Sunarti Sain, Deputy Director: Amiruddin Makka, Accounting: Nurfitriani Fatma Arifin. General / Personnel and Advertising Manager: Nurjannah. Circulation and promotion coordinator: Faisal. General Leader, Editor in Chief / Person in Charge: Sunarti Sain. Editorial Staff: Muh. Irwan, Suparman, Riskandi, Haswandi Ashari, Rachmat Fajar, Anjar Sumyana, Masiga, Fitriani Salwar Sumami. Layout (Oracetak): Irfan Idris, Danial. Ad Designer / Coordinator Page: Irfan Idris. Ad Coordinator: Muh. Irwan. Correspondents: Hendra (Gowa), Wayang (Takalar), A. Indra Jaya (Jeneponto), Rizal (Bantaeng), Mutiara Rahim (Sinjai), Maulana Rahim (Sinjai), Mulawangsah (Benteng, Selayar). Faisal Kota (Bulukumba), Accunk Ronald Reagan (Ujung Bulu), Andi Basran (Ujung Loe), Alwi (Kajang), Laode Wito (Bontotiro, Herlang, Kajang).

The Radar Selatan daily was published in plano size as many as 12 pages every day. The color is printed and contains a variety of news and descriptions, among other things: Page 1 is intended for actual news about the national and regional levels. Pages 2 and 3 are Metro rubrics which contain news about Bulukumba, Pages 4 and 5 Regional Rubrics which contain news about areas around the southern tip of South Sulawesi Province, namely starting from Gowa, Takjalar, Jeneponto, Bantaeng, Bulukumba, Sinjai to Selayar. Page 6 is for news links from the previous page. Page 7 Economic Rubric which contains coverage of economic activities both national and regional. Pages 8 and 9. Page 10 is the Education Rubric which contains news about campus activities and the local Education Office, then Page 11 Sports and Entertainment Rubric which contains sports activities and the world of artists, while the last page or page 12 is the Village Window Rubric which contains news about events that occurred in the village.

South Radar Daily also includes new advertisements posted on pages 7, 9 and 11 below. Classifieds contain offers and sales in the property sector regarding land, receive food, store and advertorial orders. South Radar has a circulation area in the former Bantaeng District which includes: Under Districts Bulukumba, Jeneponto, Takalar, and Selayar. Radar Selatan also expanded its coverage to two areas outside Bantaeng district, namely Sinjai and Gowa.

\section{FINDINGS}

This study uses two methods, namely quantitative methods and qualitative methods. The quantitative method is done by coding the 2017 - 2019 edition of the Parepare Pos, Palopo Pos, Radar Bone, Radar Selatan newspapers.

\section{News Theme}

If we pay attention to the direction and inclination of the news themes raised by these two newspapers, both of them give prominence to certain themes. The Pare Pos daily has a tendency to the theme Law and Development, namely the Law 16 times the appearance and Development of 10 times the display, on the contrary Palopo Pos daily gives greater pressure on the Legal aspect as many as 19 times, while the other themes do not stand out meaning 
quite evenly on the theme socio-cultural (5) and development (4). Daily Radar Bone has 7 views in terms of law, 1 education and 3 others, while Radar Selatan Daily has a display in the legal midwife (0), while the development theme has 6 items, 5 environment items, and 3 other items.

\section{News Coverage}

In terms of news coverage, it seems that the two newspapers raised very different news coverage, namely Pare Pos giving pressure on policy issues as many as 20 times, while the Daily Palopo Pos put pressure on the Personal issues 19 times. Based on the data, it can be seen that corruption news with personal news coverage issues and policy issues get a bigger place. Corruption news that raises individuals or persons has a direct effect on corruptors, so the positive side is preventing and giving warnings to officials who have not committed corruption. While the policy issue is more on how the government in making efforts in tackling and preventing corruption. Radar Bone 11 items including personal issues (5), Policies (1) and others (5). Radar Selatan has 18 items with an emphasis on policy issues of 8 items.

\section{News Size}

In terms of the size of the news, the news of corruption is more in the medium paragraph size, both on the Daily Pare Pos (26 times the display) and Palpo Pos (24 times the display). Palopo Pos tends to preach news about the corruption in paragraphs long (13 times the appearance) compared to the Daily Pare post which is only 8 times the appearance. In the case of news, the corruption of the Palopo Pos avoids short paragraphs (no news), while Pare Pos has 4 news of corruption in a short paragraph size. Radar Bone from 11 news, 7 of which are in the long paragraph category and 1 in the medium category. Radar Selatan from 15 news researched, 10 of them are considered to have long paragraphs and 5 are medium.

\section{News Level}

In this section, the study wants to show that local media in reporting corruption almost $90 \%$ gives a portion of local news / issues. Local / regional news made the most news with 29 news views. From the national level news there were only 8 stories in the Palopo Pos newspaper, while Pare Pos all had local contents with $100 \%$ of 38 corruption news, while Pare Pos are all locally charged with $100 \%$ of 38 corruption news. Radar Bone all news at the district level (100\%), as well as at the Radar Selatan Daily 15 (100\%) the news level is district or local news.

\section{News Placement}

The placement of news in the agenda setting study shows how important an event is in the media view. In terms of the appearance or appearance of the news about Law or Corruption, it seems that the two newspapers have different characteristics, where Palopo Pos has the most news (24 views) on page 1 but not in the form of headlines, on the contrary Pare Pos forges corruption news not on page 1 as many as 28 views. Radar Bone, featuring more corruption news not on page 1 (headline) that is 7 out of 11 news, as well as Radar Selatan showing corruption news not on page 1 (headline) which is 10 out of 15 news.

\section{News support}

To complete the news displayed, the two newspapers also show differences, namely the Pare Pos Daily completes the news that is displayed with photo images (as many as 22 views), while the Palopo Pos Daily does not have a photographic image, but in graphic form there are 8 display times. Different from the Daily Radar Bone, 11 news (100\%) corruption news accompanied by photos, while the Radar Selatan Daily 12 (80\%) of 15 news are accompanied by photos. 


\section{Objectivity News}

The problem of objectivity is that news is always interesting in a media conversation, although in theory it is often said that pure objectivity is very difficult to achieve in full, because of the influence of the intervention of the news writer himself. In relation to the objectivity of the news, the accuracy of the Daily Pare Pos is higher at 36 times, compared to Palopo Pos daily only 29 times. But there is one thing that is quite contradictory is the completeness of the news, it seems that the Palopo Pos in news writing meets the standard $5 \mathrm{~W} 1 \mathrm{H}$ with 28 views, while the Pos Pare is only 27 times, although the difference is not significant. Daily Radar Bone $9(81.9 \%)$ of the 11 news that were studied complied with $5 \mathrm{~W}$ and $1 \mathrm{H}$, just as the South Radar Daily 13 out of 15 researched news fulfilled $5 \mathrm{~W}$ and $1 \mathrm{H}$. Same as Radar Selatan also 100\% in accordance with the title of the news and have checked and re-checked, but in order to be less in terms of both sides cover that is only 6 out of 15 news.

\section{Horse Race Journalism}

This section aims to look at the style of news from a corruption story. Referring to the method developed by Pew Research in the United States, News Style can be seen in two aspects, namely: (1) Horse race: A news style that sees aspects of corruption as a race arena. Like horse racing, this type of corruption news focuses on the excitement of a match. (2) Non horse race. This style is contrary to the Horse race style. This means that news of corruption is present in a broader face. The journalistic style of the race horse (Horse Race) that pits between two news objects is often also done by journalists to extract information and direct the attention of readers or viewers.

In this connection both newspapers seem to be trying not to use journalistic methods like this. It can be seen that both the Post Pare and the Post Palopo have a high level of frequency for not using journalistic horse race, namely 34 assessments for Pos Pare, and 28 ratings for the Post Palopo. This means that Palopo Pos still uses journalistic methods like this even though the frequency level is not so high, which is only 9 times while Post Pare is 4 times.

Different conditions were found in the Radar Bone Daily where 100 percent of the news were categorized as non-horse race, and the Radar Selatan Daily published corruption news which was generally non-horse (14 out of 15 news).

\section{Tone News}

To see the nature or tone of the news published in this newspaper, it seems that both Pos Pare and Palopo Pos, tend to have similarities, which are more neutral than siding, which is 29 times the appearance of Palopo Pos and 23 times at Pos Pare, but there seems to be 10 ratings Pare Pos news tends to side with a news object, while the Palopo Pos does not exist at all. The same thing was also found in the Radar Bone Daily where 11 news stories of corruption that appeared tend to be negative. Unlike the Radar Selatan Daily tend to be neutral (9 out of 15 news) and only 4 news found negative.

\section{News Value}

News is a report that contains information about something new, or is happening. News can be delivered in print, broadcast, internet or word of mouth. News has become a necessity for the wider community. But not all information about something that happened in this world deserves to be made into a news story. There are certain values that must be fulfilled so that a news is considered important to be broadcast through the mass media.

These values include: Magnitude. The extent of the influence of a news for the community (Magnitude) determines whether the news is valuable or not. This value indicates the 
magnitude or weight of an event. Prominence. Something that stands out and is attached to someone's character, for example achievement, accident, lifestyle, and others. Conflict or Controversy. Information that contains conflict and controversy clearly has a high enough value. Timeliness. The value of freshness or novelty is very important. The faster the information about the event reaches the public, the better. (K.Agee et al: 1983) A new thing, which is unknown to others, that has not been published will attract many people. Sensation. Big events are called sensations or shocking but small events that are exaggerated are called sensational. Sensational is not justified because it is contrary to the actual situation (not factual). Large events (containing also magnitude) are commonly called scope. Human interest. Relating to human interests. Unique. This is a generally accepted value about something unique. For example, a four-eyed cow or a cat speaking cat is something that is interesting to cover.

In terms of magnitude, both newspapers are trying to raise something new and interesting for the reader, this can be seen from the data that the Pos Pare displays 36 times the news display that has a vibration value, and Palopo Pos has 25 times the same news type. Other things like conflict, sensional news, unique are not prominent, except the type of prominence and human interest get a portion in Palopo Pos daily but the frequency is not large. In the Radar Bone Daily the news tends to be sensional news (6) and prominence (3), whereas on the Radar Selatan Daily there are 6 prominence and 5 sensional news, others are timeless and unique.

\section{News Orientation}

The orientation or origin of the news was also reviewed to see where the journalists from both newspapers got the news. From the analysis of the data, it seems that the two newspapers almost have similarities, namely Pare Pos obtained information from the facts as many as 21 times, while Palopo Pos 19 times. Likewise, the two newspapers were talking news or news sourced from interviews with almost the same informants namely Pare News as many as 17 views and Palopo Pos as many as 18 times. Radar Bone Daily 100 corruption news published is a fact, on the contrary in the Radar Selatan Daily only 9 of 15 news, the other is an interview or talking news. The conclusion that these fourth newspapers were the source of their stories came from the Facts and Results of the Talking News.

\section{Quantitative}

\section{ANALYSIS}

Based on the data collected quantitatively, the research team then compared the packaging of corruption news by comparing the size of the news by each local print media, namely Palopo Pos with Parepare Pos by using the Analysis of Variance (ANOVA) Single Factor test or onefactor ANOVA (One Way Anova). 


\begin{tabular}{|c|c|c|c|c|c|c|}
\hline \multicolumn{5}{|l|}{ SUMMARY } & & \\
\hline Groups & Count & Sum & Average & Variance & & \\
\hline Radar Bone & 3 & 36 & 12 & 277 & & \\
\hline Radar Selatan & 3 & 36 & 12 & 333 & & \\
\hline Palopo Pos & 3 & 37 & 12,33333 & 224,33333 & & \\
\hline Parepare Pos & 3 & 38 & 12,66667 & 481,33333 & & \\
\hline \multicolumn{7}{|l|}{ ANOVA } \\
\hline Source of Variation & $S S$ & $d f$ & $M S$ & $F$ & P-value & F crit \\
\hline Between Groups & 0,916666667 & 3 & 0,305556 & 0,000929 & 0,999957 & 4,066181 \\
\hline Within Groups & 2631,333333 & 8 & 328,9167 & & & \\
\hline Total & 2632,25 & 11 & & & & \\
\hline
\end{tabular}

\section{Processed using SPSS 21}

Descriptively, we can see at a glance that the average level of corruption news in the four media is relatively the same. The Radar Bone and Radar Selatan newspapers are 12 while the Palopo Pos news size is around 12.33, while the Parepare Pos newspapers are around 12.67.

In the ANOVA table above, we can see that the significance value is 0.999957 . Because $\mathrm{F}=$ $0,000929<$ Fcrit $=4,066181$, Ho is accepted. Thus, using a significance level of 5\%, it can be concluded that the average level of corruption news between Palopo Pos and Parepare Pos are the same.

\section{Qualitative Analysis}

\section{The Role of the Media in the Development of Regional Autonomy}

The presence of communication media, especially the local press in the district / region by the Regional Leadership, is considered beneficial, because it serves as a bridge or liaison between the community and the local government. The government appreciates the role of local media in disseminating government policies to the public, but the local media functions less as a means of control, because it takes on the role of a government partner.

\section{Supervision of Social Development and Services}

Local media conducts a lot of monitoring of the problems of community social services, including supervision of infrastructure development and the running of government. But it still feels incomplete and needs to be improved, because there are some things raised by the media that still need confirmation. Local media reporters must be honest and avoid negative prejudice.

Regarding the presence of local media which is feared to be able to disrupt the running of government is considered incorrect, because the media are expected to be a bridge between the government and the community. The task of the media is to oversee government and development, therefore the relationship between the media and the government should not need to be too close and also not necessarily too far.

In writing news about corruption and also the problems of development and public services, journalists should not make opinions, journalists should not write what is in their hearts. The media is expected to be able to make objective reports in accordance with the facts and keep away from opinions that can side with a problem 


\section{Cooperation}

Local media helps the police apparatus and the practice of reporting on the administration of authority, corruption or other crimes. Therefore cooperation between law enforcement officials (police and prosecutors) and the media is expected to be more synergic in building a clean government and making deterrent effects for people who want to try corruption. The government needs media instead the media also need the government. Collaboration between media and Non Government Organizations SM is needed to support each other in the disclosure of cases of corruption or abuse of authority. NGOs can be a source of information or channeled through police or prosecutors where the press can obtain information or directly from NGOs to the media. The media cannot depend entirely on government public relations institutions because it can eliminate its independence.

\section{Capability}

In reporting on matters relating to corruption, local media showed a cautious attitude. Journalists tried to cross-check information sources and were not in a hurry to raise the matter in the media. They need data and evidence in the form of facts, and are always reminded that journalists avoid legal offenses that can strike back at them.

Although journalists are always careful in reporting on corruption issues, they have a commitment to help the government overcome corruption, because corruption harms the state and society. In addition, local media also actively control the problems of public services such as damaged roads, illegal fees, village aid funds, garbage, new student admissions, and so on.

\section{Conclusion}

\section{CONCLUSIONS AND RECOMMENDATIONS}

Local media have played a role in carrying out their oversight function on the possibility of corruption in government institutions in the region, even though this is not solely because of the role of the media, but also because regulations and supervision carried out by the government through bureaucratic channels are strictly in order creating good and clean governance.

The portion of local media coverage of corruption is quite large, seen from the large frequency of coverage in the field of law and development compared to other themes. However, judging from the tone of the news in general, it is still nuanced with information, and there has not been much investigated reporting. This is due to the careful factor of the local media in uncovering corruption cases involving state apparatus. Therefore the principle of crosschecking information sources is very important to avoid coverage that can cause them to be subject to legal offenses. On the other hand, although both newspapers tried to be cautious in the coverage of corruption, all newspaper had a commitment to help the government overcome corruption because they realized that it was detrimental to the state and society.

Judging from the frequency and nature of coverage between the Daily Pare Pos, the Daily Palopo Pos, Radar Bone and South Radar in reporting issues of corruption, it does not seem to show a significant difference, although it seems that the Palopo Pos Daily and Radar Bone daily are quite sharp in the disclosure of news the field of law such as corruption and the use of authority of the apparatus compared with the Daily Pare Pos and South Radar. The Daily Pare Pos and Radar Selatan had cooler news tones while the Palopo Pos Daily and Bone radar were slightly more vibrant in disclosing corruption cases. In terms of the social control that is exercised, all media has a cooler news tone while the Palopo Pos Daily is a little more vibrant in disclosing corruption cases. In terms of social control carried out, both have similarities such as 
the problem of market buildings, government offices, highways, garbage, illegal fees and the like. All newspapers show high attitudes to such matters.

Regarding the barriers to carrying out journalistic duties in creating corruption cases, all newspapers admitted that they did not experience obstacles, although the Palopo Pos Daily stated implicitly but tended to decrease and improve. This is due to regional turmoil conditions on political issues at certain times, and also because of the ability of journalists to become more professional to cross-check competent information sources.

\section{Recommendations}

The preaching of local media in the field of law, especially corruption and abuse of authority of officials, has increased in frequency by providing journalists in the field of legal and journalistic investigations.

Because the nature of media coverage of corruption news is generally still informative, it has not led to education, it is recommended that interviews be conducted or raise writings from other legal and social experts who can enlighten in the field of law and corruption so that they know and are aware of that matter.

Considering the function of the media in terms of community oversight can be multidimensional, so the role that has been carried out by these four media (Pos Pare, Palopo Pos, Radar Bone, and Radar Selatan) in caring for social matters (social control) which is in direct contact with community needs such as road repairs, market development, procurement of drinking water, is continuously being increased so that the media acts as a tool for social control in society. It also requires good cooperation with the Attorney General's Office, the Police, and Community Social Institutions (NGOs) to share and complement each other in carrying out their respective duties and functions without eliminating independence and professionalism.

\section{BIBLIOGRAPHY}

Demers, David P. and Suzanne Nichols. Precious Journalism. A Practical Guide. Sage Publication, London . 1987

Dimant, Eugen. Causes and Effects of Corruption: What has Past Decade's Empirical Research Taught us? A Survey. https://www.researchgate.net/publication/31264262

Elliot, Deni (edit). Responsible Journalism. Sage Publication, London . 1986.

Fendwick, John, (1995), Managing Local Government, Chapman \& Hall, London.

Gaines, William C. Investigative Reporting for Print and Broadcast. Nelson Hall. Inc. 1998.

Goodwin, H. Eugene. Groping for Ethic in Journalism. Iowa State University Press, Ames. 1982

Holzer, Marc and Kathe Callahan. Government At Work. Sage Publication. London. 1998

Kooiman, Jan. Modern Governance : New Government - Society Interaction. Sage Publication. London. 1994

Koswara, E, (2000), Paradigma Baru Otonomi Daerah Yang Berorientasi Kepentingan Rakyat, dalam Jurnal Widyapraja, Tahun XXIV. No. 34, Jakarta.

Narbon, Isabel. Evaluating local government performance in times of crisis. Journal of Local Government Studies. Vol 45. https://www.tandfonline.com/toc/flgs20/current

Neo, Boom Siong and Chen, Geraldine. Dynamic Governance. Embedding Culture, Capabilities and Change in Singapore. World Scientific. Singapore, 2007.

Osborne, David \& Ted Gaebler, (1994), Reinventing Government : How the Entrepreneurial Spirit Transforming the public Sector

Rasyid, Ryaas. M. Mengubah Pemerintahan Indonesia. Eventa Prima Communications. Jakarta. 2003

Rivers, William L. Ethics for the Media. Prentice Hall. Englewood Cliff, New Jersey 07632. 1988. 
Soseco, Thomas. Corruption Pattern In Indonesia: A Geographical Analysis.

https://www.researchgate.net/publication/307647544, September 20

Williams, Paul N. Investigative Reporting and Editing. Prentice Hall. Englewood Cliff, New Jersey 07632. 1978 